AperTO - Archivio Istituzionale Open Access dell'Università di Torino

\title{
About Star Architecture. Reflecting on Cities in Europe
}

\section{This is the author's manuscript}

Original Citation:

Availability:

This version is available http://hdl.handle.net/2318/1795263

since 2021-07-28T17:59:50Z

Published version:

DOI:10.1177/0042098020937214

Terms of use:

Open Access

Anyone can freely access the full text of works made available as "Open Access". Works made available under a Creative Commons license can be used according to the terms and conditions of said license. Use of all other works requires consent of the right holder (author or publisher) if not exempted from copyright protection by the applicable law. 


\section{Book review}

Nadia Alaily-Mattar, Davide Ponzini and Alain Thierstein (eds), About Star Architecture. Reflecting on Cities in Europe, Springer: Cham, 2020.

\section{Alberto Vanolo}

In this edited collection, the expression 'star architectures' is mobilised in order to refer to and analyse 'exceptional architecture projects such as iconic museums, spectacular infrastructures or public spaces' (p. 1), usually (but not always) designed and signed by well-known architects, or starchitects.

The debate on star architectures in urban studies is fragmented and hence this book offers a much-welcomed systematisation. Particularly, the expression 'star architecture' has been rarely used in the literature, with the exception of works of those authors who have contributed to this edited collection, such as Ponzini and Nastasi (2011) and Gravari-Barbas and Renard-Delautre (2015). Rather, contributions in the literature focus on various related concepts without, instead, linking directly to star architecture in order to shape a distinct debate. It is particularly worth mentioning exemplary debates on iconic architectures and their relations with capitalism and urban development paradigms (most notably with the works of Kaika, 2010; Sklair, 2006, 2017); on cultural flagship projects, including the pivotal case of Bilbao and its famous 'effect' (Gonzales, 2011); on the role of architectural projects in relation to spectacularisation, city branding, mega-events and massive touristification (see e.g. Jensen, 2007). The contributions in this book build on these literatures but they also take specific and distinct positions: as described in the opening of the book, the expression 'star architecture' differs from others such as 'flagship' and 'iconic building' as it emphasises the exceptionality and recognition status of the urban projects without explicitly 
referring to their effects, impact or style (e.g. iconicity). Still, the book does not extensively speculate on the idea of exceptionality (for example, there are no references to debates on 'spaces of exception', which have been influential in both political geography and urban studies): exceptionality is implicitly intended as a discursive construction or, putting it differently, it means representing or perceiving certain architects and/or their signed architectural projects as exceptional.

The book presents and analyses a number of European case studies, organised along four central sections: 'Approaching star architecture in and across cities in Europe', 'Star architecture and the media', 'Urban performances of star architecture' and 'Star architecture in heritage rich cities'. In the opening and closing chapters, the Editors argue that the choice to focus on Europe is not simply an arbitrary delimitation, as there is something specific about European star architectures: (1) the presence of democratic processes generating star architectures; (2) similar urban governance because of the presence of the European Union; (3) the relevance of built heritages which generate specific urban problems, solutions and effects;

(4) the presence of a common economic restructuring phase characterised by deindustrialisation, redevelopment of waterfronts, the promotion of the tertiary sector and tourism. This hypothesis connects to debates on the specificity of European cities (Bagnasco and Le Gales, 2000); nevertheless, this line of speculation is not really developed in the book but rather assumed as a premise.

The conceptual assumption at the basis of star architectures is well known: cities today are supposed to compete in a global scenario in order to attract different kinds of overlapping flows, including investments, (educated) tourists, members of the creative class, enterprises, events. In this scenario, cities position and reposition themselves using different strategies, including investments in image promotion, and star architectures have to be framed in this perspective. The authors explicitly choose not to 
propose any critique centred on neoliberalism (the word is rarely mentioned in the book) and hence they do not propose any systematic reflection on the abovementioned typical narrative of interurban competition, which is, however, accused of inconsistency. Rather, the chapters in this book focus on the multiple ways in which star architectures actually operate in European cities, how they transform physical, relational and representational spaces at different scales, how different interests and political positions emerge, how rationales, fields, discourses and conventional wisdoms are produced and reproduced through star architectures and their related practices, logics and networks.

An interesting aspect of this edited collection is the variety of approaches and disciplinary perspectives it mobilises, including quantitative and qualitative methodologies, theoretical speculations, analysis of media content, media circulation and communication styles, as well as political conflicts, economic impacts and the strategies of firms, stakeholders and professionals. This variety is much appreciated given the aforementioned weak systemisation of the theme in the literature, but I expected an even larger variety from a book such as this, for example by including perspectives on political ecology and sustainability, or ethnographic approaches focusing primarily on how star architectures are lived and experienced by people.

Overall, the chapters are coherent as they share a strong emphasis on the need to situate star architectures in cities and systematically explore their effects on urban societies. This is a crucial point as star architectures often assume ambiguous positions: on the one hand they are supposed to be unique and exceptional and, on the other, they are also apparently placeless and are implicitly related to ideas of replicability and transferability, as testified by the global circulation of 'models' and imitational strategies (Gonzales, 2011; see also the classic article by David Harvey, 1989).

The contributions in this book clearly analyse how signature buildings do not operate in any way in isolation from their urban contexts but rather they interact with a variety of 
social, economic, cultural, material, political and ideological conditions in the city at different scales, and architectures themselves are both products and processes which are experienced in place. With this perspective in mind, it is possible, for example, to mention the contributions by Laura Lieto (Chapter 2), who mobilises the concept of assemblage, intending star architects and their buildings as socio-material network effects enacted and performed by mobilising a variety of skills, technologies, materials and forms of knowledge; Giovanni Semi and Magda Bolzoni (Chapter 5), who explore the world of transnational firms operating in the field of urban design; Michele Nastasi (Chapter 8), who focuses on different typologies of images and photos and on what their role is in communication; Maria Gravi-Barbas (Chapter 13), who analyses architecture as a 'spatial event' affecting tourism patterns in Paris; or Sandra Guinand (Chapter 17), who maps conflicts, arguments and renegotiations in relation to a controversial project compromising the visual integrity of Vienna's skyline.

The book is richly illustrated with more than 80 colour images. The visual dimension of star architectures is crucial and pictures play an important role in this edited collection. They not only represent star architectures but they also contribute in providing a sense of places (with images of people engaging in everyday activities), performances (notably the double-paged picture of Jean Nouvel delivering a speech to stakeholders and donors in Lucerne, pp. 198-199), representational exercises (Instagram pictures, renderings, maps), data and conceptual diagrams discussed throughout this book.

As anticipated, one of the most crucial contributions of this book is offering a comprehensive systematisation of different debates in urban studies. It proposes a solid understanding of star architecture and it can potentially open the way to a number of further explorations and analytical understandings. Moreover, the book clearly may be of interest for readers beyond academia. The chapters are accurate and engage with international scholarship but they are also enjoyable and readable for practitioners and 
scholars working in fields such as architecture, communication, media and cultural studies.

The topic of star architecture is clearly huge and difficult to fully delimit, as there are clear definitional (ontological) problems given that ideas of 'star' and 'exceptionality' are relative, socially and culturally constructed, and difficult to operationalise. Surely, star architectures are transversal to a number of key contemporary debates in urban studies: as clearly discussed in the closing chapters, this book has only partially explored the field and there is certainly space for further research and theorisation.

\section{References}

Bagnasco A and Le Gales P (eds) (2000) Cities in Contemporary Europe. Cambridge: Cambridge University Press.

Gonzales S (2011) Bilbao and Barcelona 'in motion'. How urban regeneration 'models' travel and mutate in the global flows of policy tourism. Urban Studies 48(7): 13971418.

Gravari-Barbas M and Renard-Delautre C (2015) Starchitecture(s). Figures d'architectes et espace urbain / Celebrity Architects and Urban Space. Paris: L'Harmattan.

Harvey D (1989) From managerialism to entrepreneurialism: The transformation in urban governance in late capitalism. Geografiska Annaler B 71(1): 3-17.

Jensen OB (2007) Culture stories: Understanding cultural urban branding. Planning Theory 6(3): 211-236.

Kaika M (2010) Architecture and crisis: Re-inventing the icon, re-imag(in)ing London and re-branding the city. Transactions of the Institute of British Geographers 35(4): 453-474. 
Ponzini D and Nastasi M (2016) Starchitecture: Scenes, Actors and Spectacles in Contemporary Cities. New York: Monacelli.

Sklair L (2006) Iconic architecture and capitalist globalization. City 10(1): 21-47.

Sklair L (2017) The Icon Project: Architecture, Cities and Capitalist Globalization. New York: Oxford University Press. 